\title{
Perancangan Fasilitas Kerja pada Operator Pemasangan Accesories di CV. X untuk Mengurangi Risiko Musculoskeletal Disorders (MSDs)
}

\author{
Shifa Salimatusadiah*, Nur Rahman As'ad \\ Prodi Teknik Industri, Fakultas Teknik, Universitas Islam Bandung, \\ Indonesia.
}

*Shifasalimatu10@gmail.com, nur_asad@yahoo.co.id

\begin{abstract}
CV. X is a company engaged in the convection of women's bags and mini backpacks. CV. X uses the make to order process. In the process of making a mini backpack, the activities are carried out in a sitting position according to the standard, namely the sewing process, while for the process of the pattern, the cutting process, and the process of installing the accessories are done in a sitting position on the floor without a base. Based on the results of interviews with operators, it was found that the most complaints with the working conditions of the neck bowed, back bent, sat barefooted with legs crossed occurred in the operator mounting accessories. The method used is the OWAS method and the Nordic Body Map Questionnaire. Based on the results of interviews and the Nordic Body Map questionnaire, complaints were felt that consisted of neck, lower back and lower legs, knees, buttocks, and ankles. The following conditions cause muscle injury, musculoskeletal disorders. The results of the determination of work risk using the Ovako Working Analysis System (OWAS) method obtained all work elements in the process of installing accessories with the second level category, namely the process of gluing spots, cutting relief materials, linking relief and hurdles, linking spots, uniting all elements, and installing accessories.
\end{abstract}

Keywords: Nordic Body Maps, Ovako Working Analysis System (OWAS), Musculoskeletal Disorders (MsDs).

Abstrak. CV. X merupakan perusahaan yang bergerak dibidang konveksi tas wanita dan mini backpack. CV. $\mathrm{X}$ menggunakan proses make to order. Pada proses pembuatan tas mini backpack yang aktivitasnya dikerjakan dengan posisi duduk sesuai standar yaitu proses penjahitan, sedangkan untuk proses pola, proses potong, dan proses pemasangan accesories dikerjakan dengan posisi duduk dilantai tanpa alas dilakukan secara berulang ulang dan dalam jangka waktu yang lama. Berdasarkan hasil wawancara dengan operator didapatkan bahwa keluhan terbanyak dengan kondisi kerja leher menunduk, punggung membungkuk, duduk tanpa alas dengan kaki menyilang terjadi pada operator pemasangan accesories. Metode yang digunakan yaitu metode OWAS dan Kuisioner Nordic Body Map. Berdasarkan hasil dari wawancara dan kuisioner Nordic Body Map diperoleh keluhan yang dirasakan terdiri dari bagian leher, punggung atas dan bawah, lutut, bokong/paha, dan pergelangan kaki.. Hasil dari penentuan risiko kerja menggunakan metode Ovako Working Analysis System (OWAS) didapat seluruh elemen kerja pada proses pemasangan accesories dengan kategori level dua yaitu proses merekatkan bintik, menggunting bahan lega, mengaitkan lega dan gawang, mengaitkan bintik, menyatukan semua elemen, dan pemasangan accesories.

Kata Kunci: Nordic Body Maps,Ovako Working Analysis System (OWAS), Musculoskeletal Disorders(MsDs). 


\section{A. Pendahuluan}

Perkembangan bidang industri manufaktur dengan segala aktivitas produksi khususnya di negara berkembang masih banyak menggunakan mesin dan tenaga manusia terutama kegiatan yang bersifat manual (Manual Material Handling/MMH). Akibat dari aktivitas Manual Material Handling yang tidak terkontrol salah satunya adalah Musculoskeletal Disorders (MSDs). Keluhan yang terjadi pada musculoskeletal disorders (MSDs) yaitu nyeri pergelangan tangan, nyeri leher, nyeri pada punggung serta nyeri pada siku dan kaki. Tarwaka (2004), menurutnya musculoskeletal disorders (MSDs) yaitu keluhan yang terjadi pada bagian-bagian otot skeletal yang dirasakan oleh seseorang mulai dari adanya keluhan yang sangat ringan sampai keluhan sangat sakit. Keluhan yang terjadi pada musculoskeletal disorders (MSDs) yaitu nyeri pergelangan tangan, nyeri leher, nyeri pada punggung serta nyeri pada siku dan kaki.

CV. X perusahaan yang berdiri sejak 2005 yang beralamat di jalan Cibaduyut No.193, merupakan perusahaan yang bergerak dibidang konveksi tas wanita dan mini backpack. Berdasarkan hasil wawancara dengan operator didapatkan bahwa keluhan terbanyak dengan kondisi kerja leher menunduk, punggung membungkuk, duduk tanpa alas dengan kaki menyilang terjadi pada operator pemasangan accesories. Permasalahan tersebut menjadi alasan pengambilan studi kasus dikarenakan operator kerja yang lain masih dalam keadaan standar atau normal dengan fasilitas kerja yang sesuai.

Fasilitas kerja yang kurang menunjang serta aktivitas kerja yang dilakukan secara berulang-ulang mengakibatkan operator merasakan pegal pada kedua tangan, pinggang, punggung dan bahu yang selalu membungkuk kedepan, selain itu mengeluhkan pegal pada kaki dan bokong karena duduk menyilang tanpa alas dalam jangka waktu selama 8 jam kerja mengakibatkan operator mengalami gangguan otot skeletal yang terjadi karena adanya peregangan otot yang berlebihan, serta aktivitas yang dilakukan berulang dalam jangka waktu yang lama dan sikap kerja tidak alamiah (Tarwaka, Bakri dan Sudiajeng, 2004). Berdasarkan latar belakang yang telah diuraikan, maka perumusan masalah dalam penelitian ini sebagai berikut:

1. Apa saja keluhan yang dirasakan operator pemasangan accesories dengan postur kerja saat ini?

2. Bagaimana risiko yang terjadi pada proses pemasangan accesories?

3. Bagaimana perancangan fasilitas kerja operator pemasangan accesories agar dapat mengatasi masalah yang terjadi saat ini?

\section{B. Landasan Teori}

Ergonomi adalah ilmu yang membahas tentang segala aspek yang terdiri dari manusia di dalam lingkungan kerja yang dapat secara anatomi, psikologi, fisiologi, engineering, optimasi, efisiendi, kesehatan, manajemen, desain/perancangan, keselamatan dan kenyamanan di tempat kerja, rumah dan tempat rekreasi. Ergonomi adalah "Fuman Factors", selain itu ergonomi juga digunakan oleh berbagai macam ahli yaitu ahli anatomi, arsitektur, perancangan produk industri, fisika, fisioterapi, terapi pekerjaan, psikologi dan teknik industri. (Internasional Ergonomics Association). Ergonomi diterapkan pada bidang psikologi, fisiologi, analisis, perancangan sintesis, evaluasi proses kerja dan produk bagi wiraswastawan, manajer, pemerintahan, militer, dosen dan mahasiswa. (Nurmianto, 2004).

MSDs merupakan cidera otot pada sistem syaraf yaitu otot, tendon, ligament, tulang sendi, tulang rawan atapun pembuluh darah. MSDs memiliki rasa sakit seperti kaku, nyeri, panas/terbakar, kesemutan, mati rasa, dingin dan rasa tidak nyaman. MSDs memiliki keluhan yang beragam dari mulai keluhan pada otot dengan keluhan ringan sampai terasa sangat sakit. Jika otot melakukan beban secara berulang dengan jangkan waktu yang lama dapat menyebabkan kerusakan pada bagian sendi, tendon dan ligamen.

Kuesioner Nordic Body Map merupakan salah satu bentuk kuesioner checklist ergonomi. Bentuk lain dari checklist ergonomi adalah checklist International Labour Organization (ILO). Namun kuesioner Nordic Body Map adalah kuesioner yang paling sering digunakan untuk mengetahui ketidaknyamanan pada para pekerja, dan kuesioner ini paling sering digunakan karena sudah terstandarisasi dan tersusun rapi. Survei ini menggunakan 
banyak pilihan jawaban yang terdiri dari dua bagian yaitu bagian umum dan terperinci.

Cara pengisian kuesioner Nordic Body Map ini bertujuan untuk mengetahui bagian tubuh dari pekerja yang terasa sakit sebelum dan sesudah melakukan pekerjaan pada stasiun kerja. Kuesioner ini menggunakan gambar tubuh manusia yang sudah dibagi menjadi Sembilan (9) bagian utama, yaitu (Kroemer, 2001) :

1. Bahu

2. Punggunng bagian atas

3. Leher

4. Punggung bagian bawah

5. Siku

6. Pergelangan tangan/tangan

7. Tumit

8. kaki

9. pinggang

OWAS merupakan suatu metode yang digunakan untuk melakukan pengukuran tubuh dimana prinsip pengukuran yang digunakan adalah keseluruhan aktivitas kerja direkapitulasi, dibagi ke beberapa interval waktu (detik atau menit), sehingga diperoleh beberapa sampling postur kerja dari suatu siklus kerja dan/atau aktivitas lalu diadakan suatu pengukuran terhadap sampling dari siklus kerja tersebut.

Penilaian tersebut digabungkan untuk melakukan perbaikan kondisi bagian postur tubuh yang beresiko terhadap kecelakaan. Secara jelas penilaian postur tubuh pada saat bekerja dapat ditunjukkan sebagai berikut:

Penilaian pada punggung (back) diberikan kriteria nilai 1 s.d 4 ditunjukkan pada Gambar 1.

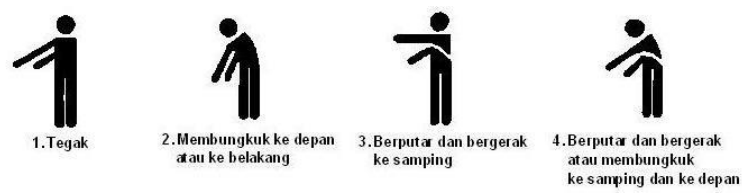

Gambar 1. Gambar Penilaian pada punggung (back)

Sumber: Anggraini., Anda. 2012

Penilaian pada lengan (arms) diberikan kriteria nilai 1 s.d 3 ditunjukkan pada Gambar 2.

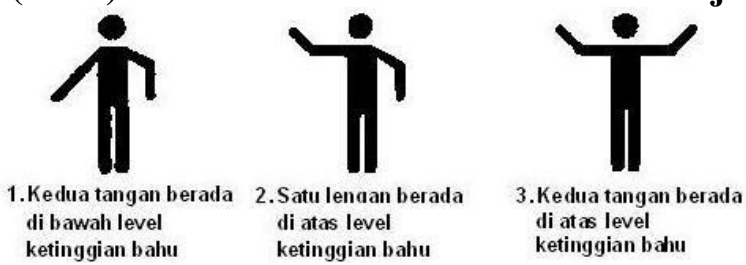

Gambar 2 Gambar Penilaian pada lengan (arms)

Sumber : Anggraini., Anda. 2012 


\section{Penilaian pada kaki (legs) diberikan kriteria nilai 1 s.d 7 ditunjukkan pada Gambar 3.}

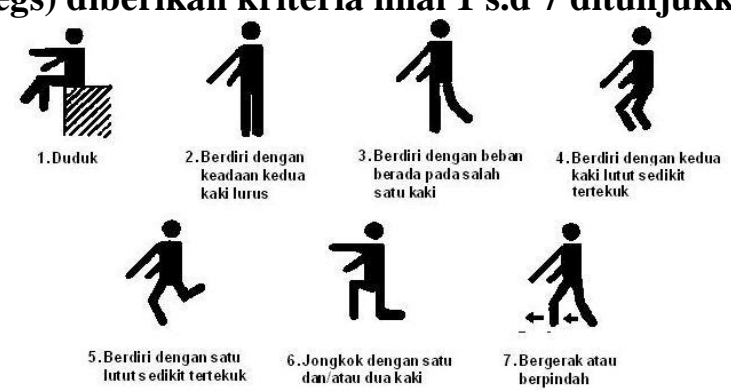

Gambar 3 Gambar Penilaian pada kaki (legs)

Sumber: Anggraini., Anda. 2012

10. Penilaian pada beban (load/use factor) diberikan kriteria nilai $1 \mathrm{s.d} 3$ yaitu sebagai berikut ini:

- Berat beban adalah kurang dari $10 \mathrm{Kg}(\mathrm{W}=10 \mathrm{Kg})$

- Berat beban adalah $10 \mathrm{Kg}-20 \mathrm{Kg}(10 \mathrm{Kg}<\mathrm{W}=20 \mathrm{Kg})$

- Berat beban adalah lebih besar dari $20 \mathrm{Kg}(\mathrm{W}>20 \mathrm{Kg}$ )

11. Tabel penilaian analisa postur kerja menggunakan metode OWAS ditunjukkan pada Tabel 1 .

Tabel 1. Tabel penilaian analisa postur kerja menggunakan metode OWAS

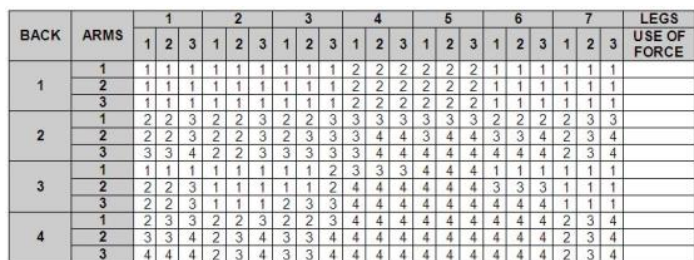

Sumber: Anggraini., Anda. 2012

12. Tabel kategori menggunakan metode OWAS ditunjukkan pada Tabel 2.

Tabel 2 Tabel kategori metode OWAS

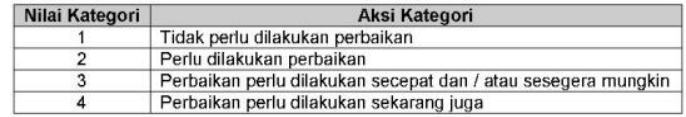

Sumber : Anggraini., Anda. 2012

Istilah antropometri berasal dari "anthro" yang berarti manusia dan "metri" yang berarti ukuran. Antropometri adalah satu kumpulan data numerik yang berhubungan dengan karakteritik fisik ukuran tubuh manusia, bentuk, dan kekuatan serta penerapan dari data tersebut untuk penanganan masalah desain (Nurmianto, 2008). Antropometri dibagi ke dalam dua bagian, yaitu:

\section{Antropometri. Statis}

Antropometri. statis. lebih. berhubungan. dengan. pengukuran. ciri-ciri. fisik. manusia. dalam. keadaan. statis. (diam). yang. .distandarkan.

\section{Antropometri Dinamis}

Antropometri dinamis lebih berhubungan dengan pengukuran ciri-ciri fisik manusia dalam keadaan dinamis, di mana dimensi tubuh yang diukur dilakukan dalam berbagai posisi tubuh 
ketika sedang bergerak sehingga lebih kompleks dan sulit dilakukan.

Data antropometri akan menentukan bentuk, ukuran, dan dimensi yang tepat berkaitan dengan produk yang dirancang dan manusia yang akan memakai produk tersebut, dalam hal ini kegiatan perancangan peralatan kerja ini harus mampu mengakomodasikan dimensi tubuh dan populasi terbesar yang akan menggunakan produk hasil rancangan tersebut.

\section{Hasil Penelitian dan Pembahasan \\ Pengolahan Data}

Dari hasil rekapitulasi kuesioner Nordic Body Map pada Tabel 4.4 diatas keluhan yang dirasakan oleh operator pemasangan accesories dalam melakukan pekerjaannya dalam jangka waktu 12 bulan terakhir dan masalah menghambat aktivitas operator selama bekerja yaitu leher, punggung atas, punggung bawah, bokong/paha, lutut, dan pergelangan kaki. Keluhan leher disebabkan oleh operator pemasangan accesories yang bekerja dengan posisi leher menunduk, selain itu punggung yang membungkuk, bokong/paha yang duduk tanpa alas, lutut dan pergelangan kaki yang melipat dengan duduk menyilang tanpa alas duduk. Selain itu keluhan yang sama dirasakan oleh operator selama 7 hari terakhir disebabkan karena tidak dilakukan perubahan pada posisi kerja serta fasilitas yang tidak sesuai dengan operator pemasangan accesories.

Pada penilaian tingkat rasa sakit dibagi menjadi 3 yaitu ringan $(<5)$, sedang $(5)$, sakit $(>5)$. Hasil dari penilaian tingkat rasa sakit yang dirasakan yang dikategorikan 'sakit' pada kedua operator yaitu pada bagian leher, punggung atas, punggung bawah, bokong/paha, lutut, dan pergelangan kaki. Sedangkan bagian tubuh dalam kategori 'ringan' yaitu siku dan pergelangan tangan.

Penentuan risiko kerja ini yaitu mengolah hasil dari penilaian postur tubuh menjadi kode postur kerja. Kode tersebut dimasukan kedalam tabel kategori dari tindakan kerja. Penentuan risiko kerja pada operator 1 pada elemen kerja merekatkan bintik.

\section{Sikap Punggung}

Pada saat elemen kerja merekatkan bintik operator bekerja dengan posisi punggung membungkuk dan leher menunduk kebawah. Penentuan skor metode OWAS pada Gambar 1 didapat skor 2 untuk posisi punggung.

\section{Sikap Lengan}

Pada saat elemen kerja merekatkan bintik operator bekerja dengan posisi kedua tangan berada dibawah ketinggian bahu. Penentuan skor metode OWAS pada Gambar 2 didapat skor 1 untuk posisi lengan.

\section{Sikap Kaki}

Pada saat elemen kerja merekatkan bintik operator bekerja dengan posisi kedua kaki melipat dan menyilang. Penentuan skor metode OWAS pada Gambar 3 didapat skor 1 untuk posisi kaki. Berat Beban

Pada saat elemen kerja merekatkan bintik operator bekerja dengan berat beban kurang dari 10kg. Penentuan skor metode OWAS didapat skor 1 untuk berat beban.

Berdasarkan hasil penilaian risiko kerja untuk setiap bagian tubuh yang dinilai pada elemen kerja merekatkan bintik maka didapatkan kode OWAS yaitu 2111.

Tabel 3 kategori Tindakan Kerja

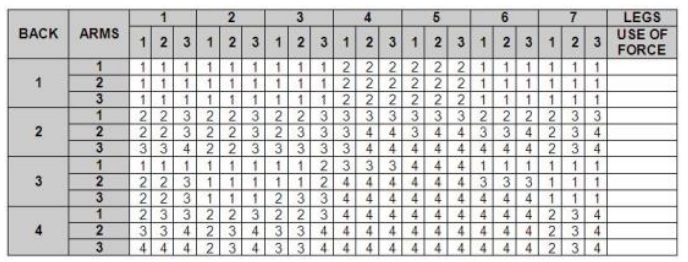

Berdasarkan penilaian risiko kerja dengan menggunakan metode OWAS dapat diperoleh hasil seluruh elemen kerja pada proses pemasangan accesories dengan kategori level dua yaitu proses merekatkan bintik, menggunting bahan lega, mengaitkan lega dan gawang, 
mengaitkan bintik, menyatukan semua elemen, dan pemasangan accesories. Level dua artinya yaitu masuk kedalam kategori tindakan perbaikan mungkin perlu dilakukan, hal ini disebabkan karena metode kerja yang dilakukan oleh operator pemasangan accesories tidak aman dilakukan berulang-ulang dalam jangka waktu yang lama dengan posisi duduk menyilang tanpa alas kaki. Tindakan perbaikan mungkin perlu dilakukan untuk mengurangi cedera musculoskeletal disorders (MsDs) yang akan terus terjadi pada operator pemasangan accesories.

Manusia memiliki keterbatasan dalam melakukan aktivitas terutama aktivitas kerja, oleh karena itu diperlukan analisa antara disiplin ilmu kesehatan dan fisiologi yang menyangkut tubuh manusia untuk mengetahui apakah cara yang digunakan sudah sesuai dengan ketentuan dan bagaimana tingkat terjadinya kecelakaan kerja serta menyesuaikan antara pekerjaan yang dikerjakan dan fasilitas yang digunakan oleh operator sudah nyaman. (Anggraini, dan Anda., 2012).

Hasil yang diperoleh dari penyebaran kuesioner Nordic Body Map pada operator pemasangan accesories didapatkan operator 1 dan operator 2 yang merasakan keluhan pada bagian tubuh dan belum pernah memeriksakan ke dokter atau terapis, sehingga jika kondisi tersebut dibiarkan secara terus menerus akan menyebabkan cedera yang lebih serius yang akan dialami operator dan akan menimbulkan aktivitas perusahaan sedikit terhambat yang berakibat keuntungan perusahaan menurun.

\section{Kesimpulan}

Berdasakan hasil penelitian dan pengolahan data yang telah dilakukan diperoleh beberapa kesimpulan sebagai berikut :

1. Pada proses pemasangan accesories yang dikerjakan oleh dua orang operator dengan sikap kerja leher menunduk, punggung membungkak, bokong/paha duduk tanpa alas, dan kaki yang menyilang. Sikap kerja tersebut menimbulkan keluhan yang dirasakan pada saat dan setelah operator sedang melakukan pekerjaannya. Hasil dari kuisioner Nordic Body Map yang telah dilakukan dan wawancara secara langsung diperoleh keluhan yang dirasakan terdiri dari bagian leher, punggung atas dan bawah, lutut, bokong/paha, dan pergelangan kaki. Bagian tubuh yang dirasakan dengan tingkat rasa sakit yang tinggi ialah bagian leher, punggung atas, punggung bawah, bokong/paha, lutut, dan pergelangan kaki. Yang diakibatkan karena posisi punggung membungkuk, leher menunduk, bokong/paha duduk tanpa alas serta pergelangan kaki yang menyilang. Sedangkan bagian tubuh dalam kategori 'ringan' yaitu siku dan pergelangan tangan. Kondisi berikut menyebabkan cedera pada otot yaitu musculoskeletal disorders.

2. Hasil dari penentuan risiko kerja menggunakan metode Ovako Working Analysis System (OWAS) didapat seluruh elemen kerja pada proses pemasangan accesories dengan kategori level dua. Yang terdiri dari proses merekatkan bintik, menggunting bahan lega, mengaitkan lega dan gawang, mengaitkan bintik, menyatukan semua elemen, dan pemasangan accesories. Level dua artinya tindakan perbaikan mungkin perlu dilakukan untuk mengurangi cedera musculoskeletal disorders (MsDs) yang akan terjadi pada operator pemasangan accesories.

3. Rancangan fasilitas kerja untuk operator pemasangan accesories yaitu membuat meja kerja yang dibuat sesuai dengan kebutuhan dan dari hasil rekomendasi menggunakan metode Ovako Working Analysis System (OWAS) serta dengan kursi yang disesuaikan. Tujuannya untuk menghilangkan keluhan pada leher yang menunduk, pungung yang membungkuk, bokong/paha duduk tanpa alas dan pergelangan kaki yang menyilang. 


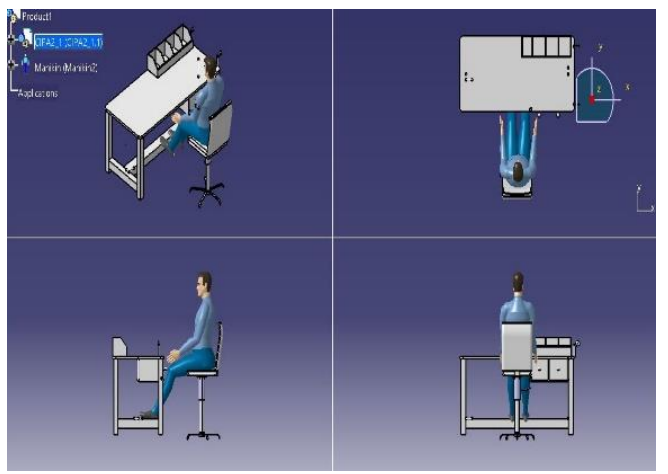

Gambar 5 Visualisasi Fasilitas Kerja

\section{E. Saran}

Berdasarkan hasil penilitian yang telah dilakukan memiliki beberapa saran yang diberikan untuk perusahaan sebagai berikut :

1. Perusahaan dapat melakukan perbaikan fasilitas kerja yang sesuai kebutuhan operator seperti meja dan kursi yang telah dirancang pada penelitian ini yang tujuannya untuk mengurangi cedera otot.

2. Selain perbaikan fasilitas kerja yaitu meja dan kursi, perusahaan dapat menambah elemen lampu pada meja kerja untuk menunjang operator pemasangan accesories yang tujuannya agar aktivitas saat merakit accesories lebih terlihat jelas oleh operator.

\section{Daftar Pustaka}

[1] Anggraini, Wresni., dan Anda Mulya Pratama. 2012. Jurnal Sains, Teknologi dan Industri, Analisis Postur Kerja Menggunakan Metode Ovako Working Analysis System (Owas) Pada Stasiun Pengepakan Bandela Karet (Studi Kasus Di Pt. Riau Crumb Rubber Factory Pekanbaru) [online] Tersedia pada: alamat web (http://ejournal.uinsuska.ac.id/index.php/sitekin/article/view/570) [Tanggal diakses 22 februari 2019]

[2] Bintang, Alfin Nur,. Dan Shanty Kusuma Dewi. 2017. Jurnal Teknik Industri, Analisis Postur Kerja Menggunakan Metode OWAS dan RULA Tersedia pada: <http://ejournal.umm.ac.id/index.php/industri/article/viewFile/4612/pdf> [Diakses tanggal 22 februari 2019]

[3] Hartono, Markus. 2012. Panduan Survei Data Antropometri. Jurusan Teknik Industri Universitas Surabaya.

[4] Iridiastadi, Hardianto dan Yassierli. 2015. Ergonomi Suatu Pengantar. Bandung : Penerbit Remaja Rosdakarya.

[5] Kroemer, K.H.E., 2001.Ergonomics: How to Design for Ease \& Efficiency, Prentice-Hall Inc.New Jersey.[Pdf].
$<$ http://repository.maranatha.edu/4696/11/0423053 Refere at 2019].

[6] Mas'idah, Fatmawat, Ajibta, 2009. Analisa Manual Material Handling(Mmh) Dengan Menggunakan Metode Biomekanika Untuk Mengidentifikasi Resiko Cidera Tulang Belakang (Musculoskeletal Disorder) [pdf] Tersedia pada: <https://media.neliti.com/media/publications/220019-analisa-manual-material-handlingmmh-den.pdf> [Diakses 12 September 2019]

[7] Nurmianto, Eko. 2008. Ergonomi, Konsep Dasar dan Aplikasinya. Surabaya: Penerbit Guna Widya.

[8] Peter, Vi., 2000, Musculoskeletal Disorders, http://www.csao.org, [online, accessed $25 \mathrm{Mei}$ 2019].

[9] Puspita Dita, Suroto, Bina Kurniawan,. 2017. “Analisis Postur Kerja Terhadap Keluhan Musculoskeletal Disorders (Msds) Pada Pekerja Mekanik Bengkel Sepeda Motor X 
Semarang", [e-journal] 5(5) Oktober 2017. Tersedia pada: website perpustakaan universitas diponegoro <http://ejournals1.undip.ac.id/index.php/jkm> [Diakses tanggal 22 februari 2019]

[10] Rahman, R. 2016. BAB II Tinjauan Pustaka. [pdf] Tersedia pada: <http://repository.unisba.ac.id/bitstream/handle/123456789/3212/06bab2_Redy\%20Rah man_10070210005_skr_2016.pdf?sequence=6\&isAllowed=y> [Diakses 12 September 2019]

[11] Suherman dan Satyo Prayogi, Hari. 2012. Analisis postur kerja pada proses maintenance excavator PC200-7 degan menggunakan metode OWAS di PT. United Tractors, Tbk PekanBaru. Jurnal Sains, Teknologi dan Industri. 9(2). Tersedia pada website, <http://ejournal.uin-suska.ac.id/index.php/sitekin/article/view/570> [Diakses 22 Mei 2019]

[12] Susanto, Dedik., 2006. Jurnal Teknik Industri, Vol. 8, No. 2, desember 2006: 148-155. Kapasitas angkat beban untuk pekerja indonesia. [diakses tanggal 16 Mei 2019]

[13] Susihono, Wahyu. 2012. Perbaikan postur kerja untuk mengurangi keluhan musculoskeletal dengan pendekatan metode owas (Studi Kasus Di UD. Rizki Ragil Jaya - Kota Cilegon). Spektrum Industri Fakultas Teknik Universitas Sultan Ageng Tirtayasa, Serang. [Diakses tanggal 16 Mei 2019]

[14] Tarwaka, Sholichul, Lilik Sudiajeng, 2004. Ergonomi Untuk Keselamatan, Kesehatan Kerja dan Produktivitas. Surakarta : UNIBA PRESS.

[15] Widanarko, dkk. 2016. Perhimpunan Ergonomi Indonesia. Kuesioner Nordic Body Map. Wignjosoebroto, Sritomo. 2000. Tata Letak Pabrik dan Pemindahan Bahan (Edisi 1). Jakarta: Penerbit PTGuna Widya.

[16] Wignjosoebroto, Sritomo, (2003), Ergonomi Studi Gerak dan Waktu, Cetakan Ketiga, Guna Widya, Jakarta.

[17] Winda A,. 2012. Faktor-Faktor Yang Berhubungan Dengan Keluhan Muskuloskeletal Pada Pekerja Angkat-Angkut Industri Pemecahan Batu Di Kecamatan Karangnongko Kabupaten Klaten, [e-journal] 1(2). Tersedia pada: website perpustakaan universitas diponegoro, <http://ejournals1.undip.ac.id/index.php/jkm> [Diakses tanggal 21 februari 2019]

[18] Xerma, 2014., Pengertian dan definisi ergonomi. [blog] 14 Desember. Tersedia pada:<http://xerma.blogspot.com/2014/12/pengertian-dan-definisi-ergonomi.html> [Diakses tanggal 22 februari 2019] 